\title{
Diversity of Batrachospermales (Rhodophyta) in the Iberian Peninsula
}

\author{
Iara S. Chapuis ${ }^{1}$, Morgan L. Vis' ${ }^{2}$, Orlando NeCchi JR. ${ }^{3 *}$, Pedro M. Sánchez \\ Castillo $^{4}$, Marina Aboal ${ }^{5}$ \& Giuseppe C. Zuccarello ${ }^{6}$
}

\author{
${ }^{1}$ Botany Department, Granada University, 18071, Granada, Spain \\ ${ }^{2}$ Department of Environmental and Plant Biology, Ohio University, Athens, OH 45701, USA \\ ${ }^{3}$ Zoology and Botany Department, São Paulo State University, 15054-000, São José do Rio Preto, SP, Brazil; \\ *Corresponding author e-mail: o.necchi@unesp.br \\ ${ }^{4}$ Botany Department, Granada University, 18071 Granada, Spain \\ ${ }^{5}$ Laboratory of Algology, Department of Plant Biology, Faculty of Biology, Espinardo Campus, 30100 Murcia, \\ Spain \\ ${ }^{6}$ School of Biological Sciences, Victoria University of Wellington, Wellington 6041, New Zealand
}

\begin{abstract}
Fifty-four streams of the Iberian Peninsula were investigated to document the species richness and phylogeny of Batrachospermum and morphologically similar genera, determine phylogenetic affinities of taxa and infer biogeographic trends. Species were identified using morphology and DNA sequence data for the rbcL gene as follows: Batrachospermum gelatinosum, B. pozoazulense, Paludicola keratophyta, Sheathia arcuata, S. boryana, S. confusa, Torularia atra, Virescentia helminthosa, V. vogesiaca, and Volatus carrionii. Batrachospermum gelatinosum and $S$. boryana were most frequent (sampled from 16 and 11 streams, respectively). Torularia atra and $V$. vogesiaca were each collected in a single stream, whereas the other five taxa were present in three to six streams. Virescentia vogesiaca is well known from other parts of Europe but had previously not been reported from the Iberian Peninsula. Biogeographic trends based on DNA sequence data show a flora with most species being well represented in parts of Europe, two taxa (B. gelatinosum and $V$. carrionii) that are shared between Europe and North America, one between Europe and South America (Paludicola keratophyta) and one cosmopolitan species (T. atra). Previous studies reported twelve taxa in the region using current taxonomy. This study has confirmed seven of these taxa with sequence data and morphology.
\end{abstract}

Key words: Batrachospermum, freshwater, Iberian Peninsula, Paludicola, phylogeny, rbcL, Sheathia, Torularia, Virescentia, Volatus

\section{INTRODUCTION}

Biodiversity of inland freshwater habitats represent a valuable natural resource, which has measurable economic, cultural, aesthetic, scientific and educational value (Gowdy 1997; Dudgeon et al. 2006). A biodiversity hotspot is an area with high species richness and frequently requiring protection (MYERS 1988; Mittermeier et al. 1999; Myers et al. 2000). The Mediterranean Basin region has been identified as a biodiversity hotspot not only for number of endemics, but also for its freshwater biotic richness and, unfortunately, for the environmental threats to its biodiversity (Malcolm et al. 2006; Cutteload et al. 2008; FigueroA et al. 2013). The Iberian Peninsula (Portugal and Spain) has freshwater habitats that are recognized as naturally rich and diverse in their biota (MéDAIL \&
DiAdema 2009; SABATER et al. 2009).

Southern European peninsulas, such as the Iberian, Italian and the Balkans appear to have been Pleistocene refugia (HewITT 2004). Numerous freshwater animal species have colonized western and northern Europe from the Iberian Peninsula after the Ice Ages (LenK et al. 1999; BeEbeE \& Rowe 2000; Durant et al. 1999; Kotlik \& Berrebi 2001; Pauls et al. 2006), but little is known about the phylogeography of freshwater macroalgae in Europe. Only a few studies have been conducted with the green alga, Aegagropila linnaei Kütz. and red alga, Batrachospermum gelatinosum (L.) DeCandole, both showing a clear imprint of recolonization of northern and central Europe from southern refugia (BoEDEKer et al. 2010; KeIL et al. 2015).

Europe has a long tradition of freshwater algal 
studies, including red algae (KYLIN 1912; SKUJA 1928; ISRAELSON 1942; REIS 1974; STARMACH 1977), yet many regions remain little explored (ELORANTA et al. 2011; CESCHI et al. 2013; ChIASSON et al. 2014). The majority of freshwater red algal studies have focused on northern and central Europe (e.g. STARMACH 1977; SiEMINSKA 1992; ATHANASIADIS 1996; KUCERA \& MARVAN 2004; GUTOWSKI et al. 2004; SCHAUMBURG et al. 2004; KOSTKEVIČIENĖ \& LAUČIŪTĖ 2005; ELORANTA \& KWANDRANS 2007; ElORANTA 2019), with only a few studies conducted in the Mediterranean Basin (REIS 1974; Sabater et al. 1989; Simic \& Rankovic 1998; CVIJAN 2002; CeSCHI et al. 2012; GarcíA-FernáNDez et al. 2015). A recent checklist of freshwater rhodophytes for the Iberian Peninsula showed this region to have a large number of taxa, many of which are in the Batrachospermales (CHAPUIS et al. 2014). In addition, a new genus Volatus and a new species of Batrachospermum in the Batrachospermales were described from the region (CHAPUIS et al. 2017). These studies hint at potentially high diversity of freshwater red algae in this region in comparison to other investigated areas in Europe (ISRAELSON 1942; REIS 1974; Chiasson et al. 2014; Eloranta 2019).

Members of the Batrachospermales have gametophytes with either a 'stick-like' morphology such as Lemanea or a 'beaded-appearance' like the nominate genus, Batrachospermum. Phylogenetic studies of the order have shown Batrachospermum to be paraphyletic and subsequently new genera that superficially resemble this genus have been described, most recently Acarposporophycos, Montagnia, Paludicola, Virescentia and Visia (NecCHI et al. 2018, 2019a, b; VIs et al. 2020). Much of the species diversity ( $90 \%)$ is contained in these macroscopically similar genera. These taxa typically occur in high water quality locations (NECCHI et al. 1999; ELORANTA 2019). Traditionally, taxonomic identification within the Batrachospermales has been based on the morphological characteristics of the gametophyte thallus. Although morphology remains the primary means of identification, in recent years taxa have been proposed that are more easily identified using DNA sequence data due to lack of a clear morphological distinction. For example, the species of Volatus can only be distinguished with certainty from those of Kumanoa by DNA sequence data emphasizing the need for both morphological and DNA sequence data (CHAPUIS et al. 2017).

The Iberian Peninsula has been underexplored for freshwater red algal diversity especially in the recent past and the combination of both morphology and sequence data are lacking. Therefore, the aims of this study were to collect species of Batrachospermales (Batrachospermum and morphologically similar genera, excluding Lemanea and Paralemanea) from a wide geographic range of the Iberian Peninsula and to use a combination of morphological and DNA sequence data to characterize the taxa. In addition, the flora from this current study was compared with the previously reported flora and biogeographic affinities explored.

\section{Materials AND MethodS}

Fifty-four sites were sampled between February and October in the years 2011-2014 as part of a larger study of algal diversity of the Iberian Peninsula (SÁnchez CASTILlo et al. 2009). When possible, water chemistry data $(\mathrm{pH}$, specific conductance and temperature) were measured on site using an YSI 560 multiprobe (Xylem Analytics, UK) and latitude and longitude were recorded using a GPS (Table 1, Table S1, Supplemental Information). These parameters were measured aiming to detect trends of occurrence for these environmental variables for individual species. A total of 55 macroscopic gametophyte samples with Batrachospermum-like morphology were collected from these sites (Fig. 1, Table S1). All algal samples were divided into three portions after removing visible epiphytes. One portion was placed in Sass liquid (Sass 1958) for morphological examination, another was dried in silica desiccant for DNA extraction, and the third portion preserved in Sass liquid was deposited in the University of Granada Herbarium (GDA) as a voucher specimen. Samples were identified according to the morphological characters previously considered as taxonomically important (NECCHI 1990; SHEATH et al. 1993, 1994; VIS et al. 1995; KumANo 2002; SALOMAKI et al. 2014; ElORANTA et al. 2011). Samples for DNA extraction were either ground by hand in liquid nitrogen using a mortar and pestle, or a Tissuelyser Bertin (Bertin Technologies, Bordeaux, France) mod. Precellys ${ }^{\circledR 2} 24$ with 1-2 tungsten beads. DNA was extracted using the NucleoSpin Plant II Genomic mini kit (MN-Macherey-Nagel, Düren, Germany) following the manufacturer's protocol or a CTAB extraction protocol (WINNEPENNINCKX et al. 1993). A 1,282 bp fragment of the rbcL gene was amplified using the F160 and rbcLR primers (Vis et al. 1998). Amplification was conducted with the following protocol for a total volume of $30 \mu 1(1 \mu 1$ of DNA, 1X buffer of New England Biolabs buffer, $250 \mathrm{nM}$ dNTP, 0.03\% BSA, $2.5 \mathrm{mM} \mathrm{MgCl}, 7.5$ pmoles of each primer and $1 \mathrm{U}$ Taq Polymerase (NEB)). For COI-5P (664 bp), samples were amplified using GAZF1 and GAZR1 primers (SAUNDERs 2005). The amplification cycles for the $\mathrm{rbcL}$ and $\mathrm{COI}-5 \mathrm{P}$ followed those provided in SALOMAKI et al. (2014). PCR products were cleaned using Exo-SAP-IT (USB, Cleveland, Ohio, USA) according to the manufacturer's instructions. Sequencing reactions were performed using the ABI Prism BigDye ${ }^{\mathrm{TM}}$ v3.1 Terminator Cycle Sequencing Ready Reaction kit and the ABI 3100 Genetic Analyzer (Applied Biosystems) at the Ohio University Genomics Facility or were commercially sequenced (Macrogen Inc., Korea). The PCR primers and internal primers (only rbcL) were used for sequencing of both strands (VIS et al. 1998). The sequences generated were edited and assembled using Geneious v7.1.9 software (Biomatters 2014) or Sequencher 5.2.4 (gene Codes Corp., Ann Arbor, Michigan, USA) and submitted to GenBank.

The rbcL sequences were used for phylogenetic reconstruction. Since there were numerous sequences for some of the species, only one or two sequences were used as they only differ by a few base pairs within species. Fourteen sequences from the Iberian Peninsula were combined with 52 
sequences retrieved from GenBank representing the genera in the Thoreales and Batrachospermales; for the genera collected in the present study, sequence data from as many species as possible included in the dataset (Table S2, Supplemental Information). In Geneious Prime 2020.1.2 (https://www.geneious.com), sequences were assembled and aligned with MUSCLE 3.8.425 (EDGAR 2004) and analysed with Maximum likelihood (ML) using RAxML (Stamatakis 2014) and Bayesian Inference (BI) analysis using MrBayes v.3.2 (RoNQUist et al. 2012). For the ML and BI analyses, a GTR + G model was employed and support values were determined using 1,000 ML bootstrap (bs) replicates and BI posterior probabilities $(\mathrm{pp}), 3 \times 10^{6}$ generations sampling every 100 generations with the first 250 generated trees removed as burn-in.

\section{RESULTS}

The 54 sites sampled had a wide variation in environmental parameters (Table 1, Table $\mathrm{S} 1$ ): $\mathrm{pH}$ varied from 4.6 to 8.6 , specific conductance ranged from 11.5 to $1400 \mu \mathrm{S} . \mathrm{cm}^{-1}$ and the temperature varied from 8.4 to $23{ }^{\circ} \mathrm{C}$. However, most taxa occurred in streams that were neutral to alkaline ( $\mathrm{pH} 7.1-8.6)$, moderately cool to warm waters $\left(14-23^{\circ} \mathrm{C}\right)$ and with elevated ion content $\left(375-847 \mu \mathrm{S} . \mathrm{cm}^{-1}\right)$.
The 55 samples collected represent ten species. Based on morphology, the following species were recognized: Batrachospermum gelatinosum, B. pozoazulense I.S. Chapuis et M.L.Vis, Paludicola keratophyta (Bory) M.L.Vis et Necchi, Sheathia arcuata (Kylin) Salomaki et M.L.Vis, S. boryana (Sirodot) Salomaki et M.L.Vis, S. confusa (Bory) Salomaki et M.L.Vis, Torularia atra (Hudson) M.J.Wynne, Virescentia helminthosa (Bory) Necchi, D.C.Agostinho et M.L.Vis, $V$. vogesiaca (Schultz ex Skuja) Necchi, D.C.Agostinho et M.L.Vis and Volatus carrionii I.S. Chapuis et M.L. Vis. Only a single species was collected from each site, except Torularia atra and Sheathia arcuata, which were both collected at the same site (site 25, Table S1).

Sequence data of the rbcL gene could be obtained from 54 specimens and a BLAST search of GenBank showed sequence similarity to ten taxa identified by morphology in this study (Table S1). Sixteen specimens belonged to Batrachospermum gelatinosum and only varied by $0-3 \mathrm{bp}$. Among the four specimens of $B$. pozoazulense, the sequences were identical, whereas the four specimens of Paludicola keratophyta varied by $0-1$ bp and the three specimens of Virescentia helminthosa also showed little variation (0-1 bp). The species of the genus Sheathia showed the

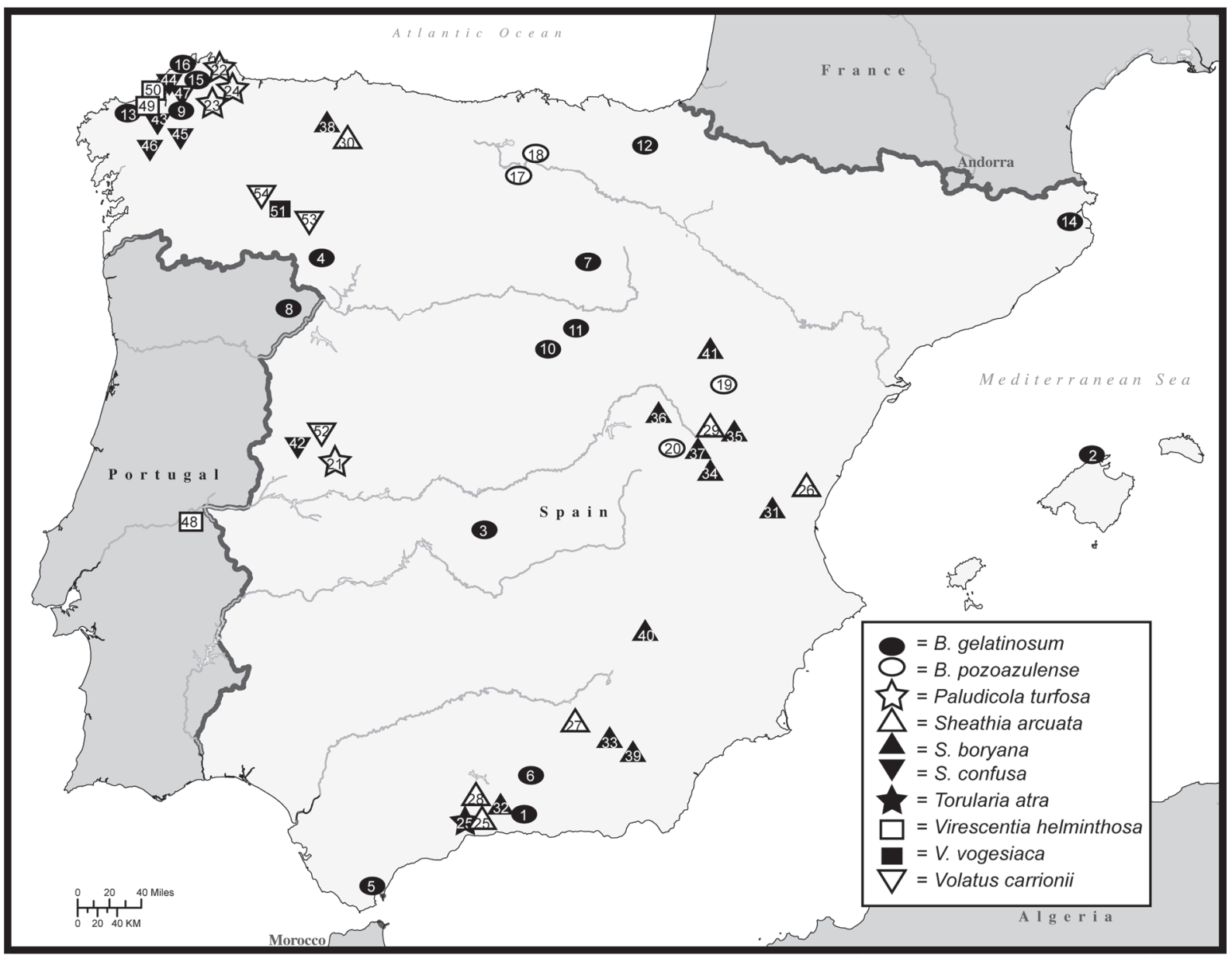

Fig. 1. Map of the Iberian Peninsula showing major rivers, and the 51 sampling localities (site numbers as in Table S1). 
Table 1. Mean (range) in stream characteristics for freshwater red algae collected. $\mathrm{n}=$ the number of streams with water chemistry data used to calculate the mean stream characteristics from the individual stream data in Table S1.

\begin{tabular}{lllll}
\hline Taxon & $\mathbf{n}$ & $\begin{array}{l}\text { Specific Conductance } \\
\left(\boldsymbol{\mu S . c m} \mathbf{S}^{-1}\right)\end{array}$ & $\mathbf{p H}$ & $\begin{array}{l}\text { Temperature } \\
\left({ }^{\circ} \mathbf{C}\right)\end{array}$ \\
\hline Batrachospermum gelatinosum & 12 & $394(54-1013)$ & $7.55(7.1-8.4)$ & $17(9-23)$ \\
B. pozoazulense & 4 & $509(436-598)$ & $7.60(7.2-8.4)$ & $13(11-15)$ \\
Paludicola keratophyta & 4 & $40(16-78)$ & $5.3(4.6-7.5)$ & $16(13-20)$ \\
Sheathia arcuata & 6 & $648(375-1237)$ & $7.55(7.3-8.3)$ & $14(8-21)$ \\
S. boryana & 11 & $654(298-1400)$ & $7.81(7.3-8.6)$ & $14(10-20)$ \\
S. confusa & 3 & $141(45-277)$ & $6.97(6.8-7.2)$ & $12(11-14)$ \\
Torularia atra & 1 & 750 & 7.9 & 13 \\
Virescentia helminthosa & 3 & $179(68-289)$ & $6.53(6.1-7.7)$ & $19(16-23)$ \\
V. vogesiaca & 1 & 12 & 7.4 & 20 \\
Volatus carrionii & 3 & $17(11-20)$ & $6.70(6.5-7.1)$ & $16(14-19)$ \\
\hline & & & &
\end{tabular}

following variation: $S$. boryana with $0-7$ bp among 11 specimens, $S$. confusa with $0-4$ bp among five specimens and $S$. arcuata with $0-3$ bp among the six specimens. The three $V$. carrionii specimens differed by $1-3$ bp. One specimen each of Virescentia helminthosa, $V$. vogesiaca and Torularia atra were confirmed from the rbcL sequences.

The sixteen COI-5P sequences represented the following taxa: Batrachospermum gelatinosum (4), B. pozoazulense (1), Paludicola keratophyta (6), Sheathia arcuata (3), S. confusa (1) and Volatus carrionii (1) (Table S1). Batrachospermum gelatinosum, Paludicola keratophyta and $S$. confusa sequences were compared with those from other regions of Europe and were either identical or differed by $\leq 2 \mathrm{bp}$. There were no sequences of Sheathia arcuata from Europe and the closest match was $S$. arcuata from China, which differed by $>7 \%$ and probably do not represent the same species. Batrachospermum pozoazulense and Volatus carrionii were recently described from Spain and these sequences were noted in the protologue.

The phylogenetic analyses of rbcL sequence data showed the tree topologies of the two reconstruction methods to be similar and only the ML tree is shown with the support values from both analyses (Fig. 2). These analyses confirmed that the specimens from this study were closely related to specimens of the same species from other locations with the exception of Batrachospermum pozoazulense and Volatus carrionii which are currently only known from the Iberian Peninsula. Six genera, Batrachospermum, Paludicola, Sheathia, Torularia, Virescentia and Volatus were represented in the flora (Fig. 2). In Batrachospermum sensu stricto, Batrachospermum gelatinosum from Spain was in a clade with sequenced specimens from North America and Europe (France and Italy). The sequences of Virescentia helminthosa and $V$. vogesia$c a$ were grouped within this genus and were similar to previously reported sequence data of specimens from France. A sequence of Paludicola keratophyta was sister to one from France. The sequence of Torularia atra was identical to a specimen from Italy. Within the genus Sheathia, the two sequences of $S$. confusa from the Iberian Peninsula were within a well-supported clade with other specimens identified as $S$. confusa collected in Europe (France) and Australasia (New Zealand). Likewise, S. arcuata was within a well-supported clade of European S. arcuata specimens collected in Bulgaria and France.

Batrachospermum was represented with two species occurring in a total of 20 streams. Batrachospermum gelatinosum was collected in 16 streams (sites 1-16, Fig. 1) including one on the Balearic Islands (site 2, Fig. 1). The streams in which this species was collected had a broad range in specific conductance $\left(54-1013 \mu \mathrm{S} . \mathrm{cm}^{-1}\right)$, neutral to alkaline $\mathrm{pH}$ (7.1-8.4) and cool to warm water temperature (13-23 $\left.{ }^{\circ} \mathrm{C}\right)$ (Tables 1, S1). Batrachospermum pozoazulense was collected from four streams in the north and east (sites 17-20, Fig. 1). The streams had moderate specif-

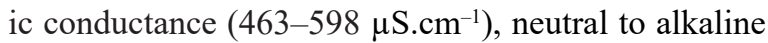
$\mathrm{pH}(7.2-8.4)$ and moderately cool water temperature $\left(11-15^{\circ} \mathrm{C}\right)$ (Table 1).

Sheathia was represented by three species observed in 23 streams. Sheathia arcuata was collected in six streams from the south to north areas of the Iberian Peninsula (sites 25-30, Fig. 1). The streams showed a broad range in specific conductance (375$\left.1237 \mu \mathrm{S} . \mathrm{cm}^{-1}\right)$, circumneutral to alkaline $\mathrm{pH}(7.3-8.3)$ and variable water temperature $\left(8-21^{\circ} \mathrm{C}\right)$ (Table 1). Sheathia boryana was collected from 11 streams, primarily located in the south and east regions of the 


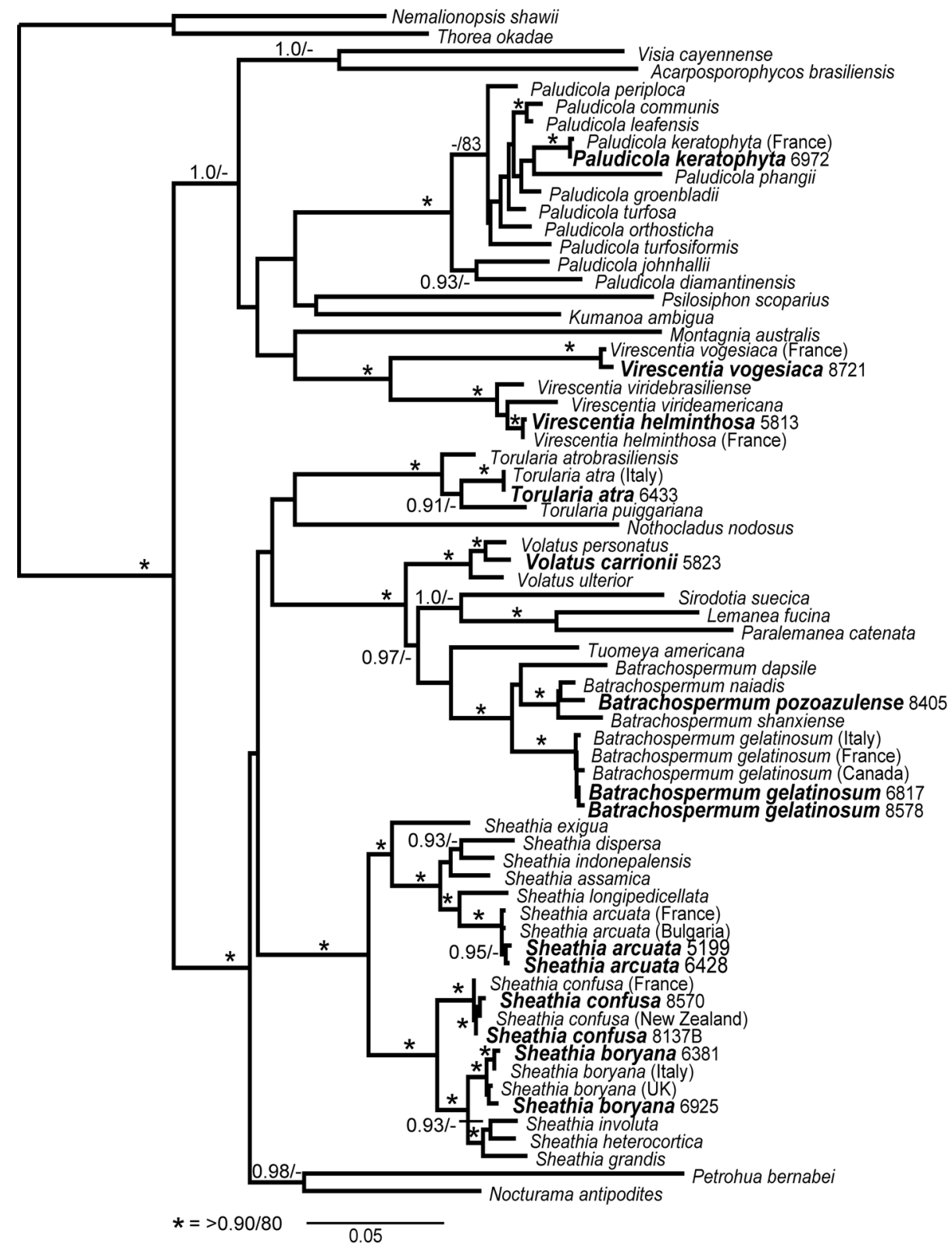

Fig. 2. Bayesian Inference (BI) phylogeny showing relationship of new specimens collected in this study (in bold) with other genera and species of Batrachospermales based on rbcL sequence data. Support values are shown with "*” = indicates $>0.9 \mathrm{PP} / 80$ bootstrap \%, a value shown as "-" indicate $<0.8 \mathrm{PP} / 80$ bootstrap $\%$ and no value on branches indicates a different topology in the ML tree. The outgroups (Thorea okadae and Nemalionopsis shawii) were pruned. Specimens code as in Table S2.

Peninsula with the exception of two northern localities (sites $31-41$, Fig. 1). The streams where this species occurred showed a wide range of specific conductance $\left(298-1400 \mu \mathrm{S} . \mathrm{cm}^{-1}\right)$, circumneutral to alkaline $\mathrm{pH}$ (7.3-8.6) and cool to warm water temperature $\left(10-20{ }^{\circ} \mathrm{C}\right)$ (Table 1). S. confusa was collected from six streams in the north-western Iberian Peninsula (sites 42-47, Fig. 1). The streams had relatively low specific conductance $\left(45-277 \mu \mathrm{S} . \mathrm{cm}^{-1}\right)$, circumneutral $\mathrm{pH}(6.8-7.2)$ and cool water temperature $\left(11-14{ }^{\circ} \mathrm{C}\right)$ (Table 1).

Two species of the genus Virescentia were collected from a total of four streams. $V$. helminthosa was observed in three sites (48-50, Fig. 1) with two north-western streams (sites 49-50) and one close to a hot spring in the east of the Iberian Peninsula (site 48). The streams with $V$. helminthosa had low conductivity $\left(68-289 \mu \mathrm{S} . \mathrm{cm}^{-1}\right)$, wide range in $\mathrm{pH}(6.1-7.7)$ and moderate water temperature $\left(16-23^{\circ} \mathrm{C}\right)$ (Table 1). Virescentia vogesiaca was found in a north-western stream (site 51, Fig. 1) characterized by low light levels due to dense canopy cover and high current velocity as well as very low conductivity $\left(12 \mu \mathrm{S} . \mathrm{cm}^{-1}\right), \mathrm{pH} 7.4$ and water temperature $20^{\circ} \mathrm{C}$ (Table 1).

The genera Paludicola, Volatus and Torularia were each represented by a single species. Paludicola keratophyta was collected at four locations in the west and northwest portions of the Iberian Peninsula (sites 
21-24, Fig. 1). The streams had low specific conductance $\left(16-78 \mu \mathrm{S} . \mathrm{cm}^{-1}\right)$, acidic to circumneutral $\mathrm{pH}$ (4.6-7.5) and moderately cool water temperature (13$20{ }^{\circ} \mathrm{C}$ ) (Table 1). Volatus carrionii occurred in three streams in the western and northwestern regions of the Iberian Peninsula (sites 52-54, Fig. 1). The streams had very low specific conductance $\left(11-20 \mu \mathrm{S} . \mathrm{cm}^{-1}\right)$, mildly acidic $\mathrm{pH}(6.5-6.7)$ and cool to moderately cool water temperature $\left(14-19^{\circ} \mathrm{C}\right)$ (Table 1). Torularia atra was collected from a single location (site 25, Fig. 1), having high specific conductance $\left(750 \mu{\mathrm{S} . \mathrm{cm}^{-1}}^{-}\right)$, alkaline $\mathrm{pH}(7.9)$ and cool water temperature $\left(13^{\circ} \mathrm{C}\right)$ (Table 1).

\section{DiscuSsion}

This research extends the previous limited studies of the diversity of freshwater rhodophytes from the Iberian Peninsula. In a checklist of all literature on the region, CHApuIs et al. (2014) listed 29 Batrachospermum-like species. Applying the most recent taxonomy, this number would be 12 taxa as follows: Batrachospermum gelatinosum, Kumanoa henriquesiana (Reis) Necchi et M.L.Vis, K. lusitanica (Reis) Necchi et M.L.Vis, K. pseudocarpa (Reis) Necchi et M.L.Vis, Sheathia arcuata, S. boryana, S. confusa, S. exigua, Paludicola keratophyta, Virescentia helminthosa, V. gulbenkiana (Reis) Necchi, D.C.Agostinho et M.L.Vis and Torularia atra. The current study has confirmed seven of these taxa with sequence data and morphology, whereas five species previously recorded were not found in this survey: K. henriquesisana, K. lusitanica, K. pseudocarpa, S. exigua and V. gulbenkiana. Sequence data will be important in further taxonomic revisions within the order Batrachospermales not only in the European framework, but also in a global context to delineate floras and investigate biogeographic trends.

Two species of Batrachospermum were reported in this study, B. gelatinosum and B. pozoazulense. The former is widely distributed in both North America and Europe but differs by only a few base pairs in the rbcL gene from all these locations (House et al. 2010; KEIL et al. 2015). Despite the wide geographic distribution of B. gelatinosum in the Northern Hemisphere (SHEATH \& SHERwood 2002; House et al. 2010; Eloranta et al. 2011; KeIL et al. 2015), there are few data on the physical and chemical characteristics of the streams for which there are molecular data for specimens. Three recent studies of streams in France and Italy report $B$. gelatinosum from a wide range of stream parameters: specific conductance $\left(110-825 \mu \mathrm{S} . \mathrm{cm}^{-1}\right), \mathrm{pH}(6.5-8.4)$, and temperature $\left(9-26^{\circ} \mathrm{C}\right)$, similar to the current and previous studies (CESCHI et al. 2013; CHIASSON et al. 2014; AbDelahad et al. 2015). SHEATH \& Vis (2015) also confirm the broader environmental tolerance of B. gelatinosum in North America. B. pozoazulense is a newly described species from four streams with narrow environmental ranges (CHAPUIS et al. 2017). Since this species can only be distinguished from $B$. gelatinosum with molecular data, in the future it may become known from more locations and may be shown to have a wider environmental tolerance like $B$. gelatinosum.

Two species of Virescentia were identified ( $V$. helminthosa and $V$. vogesiaca), the latter is reported for the first time in the Iberian Peninsula (CHAPUIS et al. 2014). The environmental parameters recorded for the site of $V$. helminthosa in the Iberian Peninsula were within those reported by SHEATH et al. (1994) for $V$. virideamericana in North America and by AgostinHo \& NeCCHI (2014) for $V$. viridebrasiliensis in South America. In terms of the environmental characteristics of the Iberian streams containing Paludicola keratophyta, most are acidic, brown water and low specific conductance, especially those in the north-east. Reports of P. keratophyta from other European countries have also noted similar environmental conditions (Reis 1974; Chiasson et al. 2014; Eloranta 2019).

The species Sheathia boryana, S. confusa and S. arcuata are widespread in Europe (VIS et al. 2010; Eloranta et al. 2011; ChIASSON et al. 2014; SALOMAKI et al. 2014; ABDELAHAD et al. 2015). A study in Italy reported $S$. boryana from streams with similar parameters to those of the Iberian streams: specific conductance (487-597 $\mu$ S.cm $\left.{ }^{-1}\right), \mathrm{pH}(7.2-7.3)$, and temperature (15 $\left.{ }^{\circ} \mathrm{C}\right)$ (ABDELAHAD et al. 2015). The Iberian streams with S. confusa share common ecology with the populations reported in France (CHIASSON et al. 2014). In contrast, the environmental conditions in the Iberian Peninsula streams with $S$. arcuata extend the range in environmental conditions for temperature, $\mathrm{pH}$ and conductivity from those previously reported for France and Italy (CHiAsson et al. 2014; AbDELAHAD et al. 2015).

Torularia atra is a cosmopolitan species and the morphological characteristics of the specimen in this study match previous descriptions (SHEATH et al. 1993; Kumano 2002; Eloranta et al. 2011; Rossignolo \& NeCCHi 2016). Torularia atra (as Batrachospermum atrum) was reported four times previously in the Iberian Peninsula (Reis 1974, AbOAL et al. 1995; Moreno Alcaraz et al. 2013; Rossignolo \& NeCCHI 2016). The environmental conditions reported in those surveys were similar to the ones described in this study: specific conductance $\left(577-870 \mu \mathrm{S} . \mathrm{cm}^{-1}\right), \mathrm{pH}(6.4-8.1)$, and temperature $\left(14-20{ }^{\circ} \mathrm{C}\right)$.

Our morphologically identified and molecularly confirmed species data showed some species to be widespread in the world, whereas others have narrower geographic ranges. Five of the taxa identified appear to inhabit streams only in Europe including Batrachospermum pozoazulense, Sheathia arcuata, S. boryana, Virescentia helminthosa and $V$. vogesiaca. Torularia atra is distributed worldwide and Batrachospermum gelatinosum is common on two continents (Europe and North America). Three species had collections from numerous locations in Europe but 
also a single location on another continent, Paludicola keratophyta (South America), S. confusa (Australasia), Volatus carrionii (North America). These widespread species and species with disjunct distributions suggest that these taxa can be dispersed long distances even though a resistant stage is unknown. Dispersal by wind or animals such as flying adult stages of insects or birds (Proctor 1959; Maguire 1963; CACERES \& Soluk 2002; VIS 2016) is a possibility, although still speculative due to the scarcity of experimental studies on dispersal of freshwater algae by waterfowl (VIs 2016). In addition, historical and ecological biogeography remain unexplored fields for stream macroalgae, making it difficult to provide other plausible explanation to the presently known distribution of members of the Batrachospermales.

\section{ACKNOWLEDGEMENTS}

We appreciate help in the collection or provision of specimens from all the collectors mentioned in this study. We thank M. Paiano, N. Muangmai, M. Preuss and D. Fernández, for their laboratory assistance. A. Amarelle and V. Díaz for their help with figure editing. Encouragement and facilitation of the study by J.S. Carrión is gratefully acknowledged. Funding during the preparation of this manuscript was provided by the Ministry for Economy and Competitiveness under the auspices of the project of the national plan I\&D+I (CGL2009-09563) and the FPI research grant to ISC (BES-2010-031303).

\section{REFERENCES}

Abdelahad, N.; Bolpagni, R.; Lasinio, G.J.; Vis, M.L.; Amadio, C.; Laini, A. \& KeIL, E. J. (2015): Distribution, morphology and ecological niche of Batrachospermum and Sheathia species (Batrachospermales, Rhodophyta) in the fontanili of the Po plain (northern Italy). - Eur. J. Phycol. 50: 318-329.

Aboal, M.; LóPez-JimÉnez, E. \& Asencio, A.D. (1995): Batrachospermum atrum Sirodot (Batrachospermales, Rhodophyceae) una nueva rodofícea para la flora algal epicontinental española. Anal. Jardín Bot. Mad. 53: 120-121.

Agostinho, D.C. \& NeCCHI, O. Jr. (2014): Systematics of the section Virescentia of the genus Batrachospermum (Batrachospermales, Rhodophyta) in Brazil. Phycologia 53: 561-570.

Athanasiadis, A. (1996): Taxonomisk litterature och biogeografi av skandinaviska ródalger och brunalger. 280 pp., Algologia, Göteborg,

Boedeker, C.; EgGert, A.; Immers, A. \& Wakana, I. (2010): Biogeography of Aegagropila linnaei (Cladophorophyceae, Chlorophyta): a widespread freshwater alga with low effective dispersal potential shows a glacial imprint in its distribution. - J. Biogeogr. 37: 1491-1503.

CAceres, C.E. \& SoluK, D.A. (2002): Blowing in the wind: a field test of overland dispersal and colonization by aquatic invertebrates. - Oecologia 131: 402-408.

Ceschi, S.; Bisceglie, S. \& Ricci, S. (2012): Contribution to knowledge of red alga (Rhodophyta) of some rivers in central Italy. - Cryptogamie Algol. 33: 61-67.

Ceschi, S.; Ricci, S.; Abati, S.; Bisceglie, S.; Minciardi,
M.R. \& Zuccarello, V. (2013): Distribution and ecology of red algae in Italian rivers. - Fund. Appl. Limnol. 183: 223-237.

Chapuis, I.S.; Sánchez Castillo, P.M. \& Aboal, M. (2014): Checklist of freshwater red algae in the Iberian Peninsula and the Balearic Islands. - Nova Hedwigia 98: 213-232.

Chapuis, I.S.; Necchi, O. JR.; Zuccarello, G.C.; XIe, S.L.; Aboal, M.; SÁnChez Castillo, P.M. \& Vis, M.L. (2017): A new genus, Volatus and four new species of Batrachospermum sensu stricto (Batrachospermales, Rhodophyta). - Phycologia 56: 454-468.

Chiasson, W.B.; Salomaki, E.D. \& Vis, M.L. (2014): New collections of freshwater red algae (Batrachospermales, Rhodophyta) from historically important areas in France. - Cryptogamie Algol. 35: 303-316.

Cvisan, M. (2002): A review Material for the algae flora of Serbia II. Rhodophyta (Red Algae). - Arch. Biol. Sci. 54: $1-10$.

Dudgeon, D.; Arthington, A.H.; Gessner, M.O.; Kawabata, Z.-I.; KNowler, D.J.; LévêQue, C.; Naiman, R.J.; Prieur-Richard, A.-H.; Soto, D.; Stiassny, M.L.J. \& Sullivan, C.A. (2006): Freshwater biodiversity: importance, threats, status and conservation challenges. - Biol. Rev. 81: 163.

EDGAR, R.C. (2004): MUSCLE: multiple sequence alignment with high accuracy and high throughput. Nucleic Acids Res. 32: 1792-1797.

Eloranta, P. (2019) Freshwater red algae in Finland. - Plant Fungal Syst. 64: 41-51.

Eloranta, P. \& Kwandrans, J. (2007): Freshwater red algae (Rhodophyta). Identification guide to European taxa, particularly to those in Finland. - Norrlinia 15: $1-103$.

Eloranta, P.; KwANDRAns, J. \& Kusel-Fetzman, E. (2011): Rhodophyta and Phaeophyceae. Süßwasserflora von Mitteleuropa. - 155 pp., Spektrum Akademischer Verlag, Heidelberg.

FigueroA, J.M.T.; LóPeZ-Rodríguez, M.J.; Fenoglio, S.; SÁnchez Castillo, P.M. \& Fochetti, R. (2013): Freshwater biodiversity in the rivers of the Mediterranean Basin. - Hydrobiologia 719: 137-186.

García-FernándeZ, M.E.; VIS, M.L. \& ABOAL, M. (2015): Kumanoa mahlacensis (Batrachospermales, Rhodophyta) in a Mediterranean coastal wetland, a new species for the European continental algal flora. - Anal. Jardín Bot. Mad. 72: e018.

Gowdy, J.M. (1997): The Value of Biodiversity: Markets, Society, and Ecosystems. -Land Econ 73: 25.

Gutowski, A.; Foerster, J. \& Schaumburg, J. (2004): The use of benthic algae, excluding Diatoms and Charales, for the assessment of the ecological status of running fresh waters: a case history from Germany. - Oceanol. Hydrobiol. Stud. 33: 3-15.

HewitT, G.M. (2004): The structure of biodiversity-insights from molecular phylogeography. - Front. Zool. 1: $1-16$.

House, D.L.; Vandenbroek, A.M. \& Vis, M.L. (2010): Intraspecific genetic variation of Batrachospermum gelatinosum (Batrachospermales, Rhodophyta) in eastern North America. - Phycologia 49: 501-507.

IsRAELSON, G. (1942): The freshwater Florideae of Sweden: studies on their taxonomy, ecology, and distribution. - Symb. Bot. Upsal. 6: 1-134. 
KeIL, E.J.; Macy, T.R.; KwandRans, J.; Eloranta, P.; Tomás, P.; Aboal, M. \& VIs, M.L. (2015): Phylogeography of Batrachospermum gelatinosum (Batrachospermales, Rhodophyta) shows postglacial expansion in Europe. - Phycologia 54: 176-182.

KostKevičIIEnĖ, J. \& LauČIŪtė, R. (2005): The freshwater red algae species of Batrachospermum sect. Batrachospermum (Batrachospermales, Rhodophyta) new to Lithuania. - Bot. Lithuan. 11: 151-159.

Kotlik, P. \& BerReBi, P. (2001): Phylogeography of the barbel (Barbus barbus) assessed by mitochondrial DNA variation. - Mol. Ecol. 10: 2177-2185.

KuČERA, P. \& MARVAN, P. (2004): Taxonomy and distribution of Lemanea and Paralemanea (Lemaneaceae, Rhodophyta) in the Czech Republic. - Preslia 76: $163-174$.

Kumano, S. (2002): Freshwater red algae of the world. - 373 pp., Biopress, Bristol.

Kylin, H. (1912): Studien über die schwedischen Arten der gattung Batrachospermum Roth und Sirodotia gen. nov. - Nova Acta Reg. Soc. Sci. Upsal. 43: 1-40.

Lenk, P.; Fritz, U.; Joger, U. \& Wink, M. (1999): Mitochondrial phylogeography of the European pond turtle, Emys orbicularis (Linnaeus 1758). Mol. Ecol. 8: 1911-1922.

Maguire, B. (1963): Passive overland transport of small aquatic organisms and their colonization of isolated bodies of water. - Ecol. Monogr. 33:161-185.

Malcolm, J.R.; Liu, C.; Neilson, R.P.; Hansen, L. \& HANNAH, L. (2006): Global Warming and Extinctions of Endemic Species from Biodiversity Hotspots. Conserv. Biol. 20: 538-548.

MÉDAil, F. \& DiAdEMA, K. (2009): Glacial refugia influence plant diversity patterns in the Mediterranean Basin. J. Biogeogr. 36: 1333-1345.

Mittermeier, R. A.; Myers, N.; Mittermeier, C.G. \& RoBles GiL, P. (1999): Hotspots: Earth's biologically richest and most endangered terrestrial ecoregions. Cemex, Conservation International and Agrupation Sierra Madre. - 430 pp., CEMEX, Mexico City.

Moreno Alcaraz, J.L.; Monteagudo Canales, L. \& ABOAL, M. (2013): Morphological description and ecology of some rare macroalgae in south-central Spanish rivers (Castilla-La Mancha Region). - Anal. Jardín Bot. Mad. 70: 81-90.

Myers, N.; Mittermeier, R.A.; Mittermeier, C.G.; FonsecA, G.A. \& Kent, J. (2000): Biodiversity hotspots for conservation priorities. - Nature 403: $853-858$.

Myers N. (1988): Threatened biotas: "hotspots" in tropical forests. - Environmentalist 8: 187-208.

NeCCHI, O. Jr (1990): Revision of the genus Batrachospermum Roth (Rhodophyta, Batrachospermales) in Brazil. Bibliotheca Phycologica 84 - 201 pp., J. Cramer, Stuttgart.

NeCChi, O. Jr; Branco, C.C.C \& Branco, L.H.Z. (1999): Distribution of Rhodophyta in streams from São Paulo State, southeastern Brazil. - Arch. Hydrobiol 147: 73-89.

Necchi, O. JR; Agostinho, D.C. \& VIS, M.L. 2018. Revision of Batrachospermum section Virescentia (Batrachospermales, Rhodophyta) with the establishment of the new genus, Virescentia stat. nov. Cryptogamie Algol. 39: 313-38.

Necchi, O. JR; Garcia Fo, A.S. \& Paiano, M.O. (2019a): Revision of Batrachospermum sections Acarposporophytum and Aristata (Batrachospermales, Rhodophyta) with the establishment of the new genera Acarposporophycos and Visia. - Phytotaxa 395: 51-65.

Necchi, O. JR; Garcia Fo, A.S.; Paiano, M.O. \& Vis, M.L. (2019b): Revision of Batrachospermum section Macrospora (Batrachospermales, Rhodophyta) with the establishment of the new genus Montagnia. Phycologia 58: 582-591.

Pauls, S.U.; Lumbsch, H.T. \& HaAse, P. (2006): Phylogeography of the montane caddisfly Drusus discolor: evidence for multiple refugia and periglacial survival. - Mol. Ecol. 15: 2153-2169.

Proctor, V.W. (1959): Dispersal of freshwater algae by migratory waterbirds. - Science 130: 623-624.

ReIS, M.P. (1974): Chaves para a identificação das espécies portuguesas de Batrachospermum Roth. - An. Soc. Brot. 40: 37-129.

Ronquist, F.; Teslenko, M.; Van Der Mark, P.; Ayres, D.L.; Darling, A.; Hohna, S.; Larget, B.; LiU, L.; Suchard, M.A. \& Huelsenbeck, J.P. (2012): MrBayes 3.2: Efficient Bayesian Phylogenetic Inference and Model Choice across a Large Model Space. - Syst. Biol. 61: 539-542.

Rossignolo, N.L. \& NecChI, O. Jr. (2016): Revision of Section Setacea of the genus Batrachospermum (Batrachospermales, Rhodophyta) with emphasis on specimens from Brazil. - Phycologia 55: 337-346.

Sabater, S.; Aboal, M. \& CAMbra, J. (1989): Nuevas observaciones de rodofíceas en águas epicontinentales del NE y SE de España. - Limnetica 5: 93-100.

Sabater, S.; Feio, M.J.; Muñoz, I.; Romaní, A.M. \& GraÇa, M.A. (2009): The Iberian rivers. - In: TOCKNER, K.; UeHLINGER, U. \& RoBinson, C.T. (eds): Rivers of Europe. - 113-149 pp., Academic Press, London.

Salomaki, E.D.; Kwandrans, J.; Eloranta, P. \& Vis, M.L. (2014): Molecular and morphological evidence for Sheathia gen. nov. (Batrachospermales, Rhodophyta) and three new species. - J. Phycol. 50: 526-542.

SÁnchez Castillo, P.M.; Aboal, M.S.; Angelier, D.; Asencio Martínez, A.; Cambra, J.S; Chapus, I.S.; Chicote, A.D.; Comas, A.G.; Conforti, V.; Eloranta, P.; Hoyos, C.; Rosa, J.A.; Fanés, I.T.; Fernández, D.M.; Flora, N.A.; Galán, A.D.; Kwandrans, J.; Mateo, P.O.; Negro, A.D.; GALlEGO, I.N.; LÓPEZ, M.R.; MORENO, J.L.; MuÑOZ, G.L.; Ortiz, R.L.; Perona, E.U.; Pérez, M.C.M.; SZYMANSKA, H.; VerdugO, M.A. \& ZAKrys, B. (2009): El estúdio de las algas filamentosas en la Península Ibérica. - Bol. Soc. Esp. Ficol. 41: 23-25.

SAunders, G.W. (2005): Applying DNA barcoding to red macroalgae: a preliminary appraisal holds promise for future applications. - Philos. T. R. Soc. B 360: 1879-1888.

SASs, J. E. (1958): Botanical microtechnique, 3 ed. - 228 pp., Iowa State College Press, Ames.

Schaumburg, J.; Schranz, C.; Foerster, J.; Gutowski, A.; Hofmann, G.; Meilinger, P.; Schneider, S. \& SCHMEDTJE, U. (2004): Ecological classification of macrophytes and phytobenthos for rivers in Germany according to the Water Framework Directive. Limnologica 34: 283-301.

Sheath, R.G.; VIS, M.L \& Cole, K.M. (1993): Distribution and systematics of Batrachospermum 
(Batrachospermales, Rhodophyta) in North America. 3. Section Setacea. - J. Phycol. 29: 719-725.

Sheath, R.G.; Vis, M.L. \& COle, K.M. (1994): Distribution and systematics of Batrachospermum (Batrachospermales, Rhodophyta) in North America. 4. Section Virescentia. - J. Phycol. 30: 108-117.

SHeAth, R.G. \& SHERwood, A.R. (2002): Phylum Rhodophyta (red algae). - In: JoHn, D.M.; WhitTon, B.A. \& BRooK, A.J. (eds): The freshwater algal flora of the British Isles. An identification guide to freshwater and terrestrial algae. - pp. 123-143, Cambridge University Press, Cambridge.

Sheath, R.G. \& Vis, M.L. (2015): Freshwater red algae of North America. - In: Wehr J.D., Sheath R.G. \& KocioleK J.P (eds): Freshwater algae of North America. - pp. 237-264, Academic Press, San Diego.

Sieminska, J. (1992): Red list of threatened algae in Poland. -In: ZARZYCKI, W.; WoJeWOdA, W. \& HeINRICH, Z. (eds): List of threatened plants in Poland. -9 pp., Polska Akademia Nauk, Kraków.

Simic, S. \& Rankovic, B. (1998): New data on the distribution, morphology and ecology of red algae (Rhodophyta) in rivers of Serbia (Yugoslavia). Arch. Biol. Sci. 50: 43-50.

Skuja, H. (1928): Rhodophyceae - IX. - Acta Hor. Bot. Univ. Latv. 2: 201-209.

Starmach, K. (1977): Phaeophyta - Brunatnice, Rhodophyta - Krasnorosty. - 445 pp., Polska Akademia Nauk, Warszawa.

StAmATAKis, A. (2014): RAxML version 8: a tool for phylogenetic analysis and post-analysis of large phylogenies. - Bioinformatics 30: 1312-1313.

VIs, M.L. (2016): Biogeography of River Algae. - In: Necchi, O. JR. (ed.): River Algae. pp. 219-243, Springer Nature, Cham.

Vis, M.L.; Feng, J.; Chiasson, W.B.; Xie, S.-L.; Stancheva, R.; Entwisle, T.J.; Chou, J.-Y. \& Wang, W.-L. (2010): Investigations of the molecular and morphological variability in Batrachospermum arcuatum (Batrachospermales, Rhodophyta) from geographically distant locations. - Phycologia 49: 545-553.
Vis, M.L.; Lee, J.; Eloranta, P.; Chapuis, I.S.; Lam, D.W. \& NecCHI, O. Jr (2020): Paludicola gen. nov. and revision of the species formerly in Batrachospermum section Turfosa (Batrachospermales, Rhodophyta). J. Phycol. 56: 844-861.

Vis, M.L.; Saunders, G.W.; Sheath, R.G.; Dunse, K. \& Entwisle, T.J. (1998): Phylogeny of the Batrachospermales (Rhodophyta) inferred from $r b c \mathrm{~L}$ and $18 \mathrm{~S}$ ribosomal DNA gene sequences. - J. Phycol. 34: 341-350.

Vis, M.L.; Sheath, R.G. \& Entwisle, T.J. (1995): Morphometric analysis of Batrachospermum section Batrachospermum, (Batrachospermales, Rhodophyta) type specimens. - Eur. J. Phycol. 30: $35-55$.

Winnepenninckx, B.; Bakeljau, T. \& De Wachter, R. (1993): Extraction of high-molecular-weight DNA from molluscs. - Trends Genet. 9: 407.

Supplementary material

The following supplementary material is available for this article:

Table S1. Collection information for specimens in this study including location, collector, date, herbarium, stream data (specific conductance, $\mathrm{pH}$, and water temperature) and GenBank accession number.

Table S2. Fifty-four additional sequence data from GenBank used for phylogenetic analyses.

This material is available as part of the online article (http:// fottea.czechphycology.cz/contents)

(C) Czech Phycological Society (2021)

Received August 27, 2020

Accepted November 16, 2020 